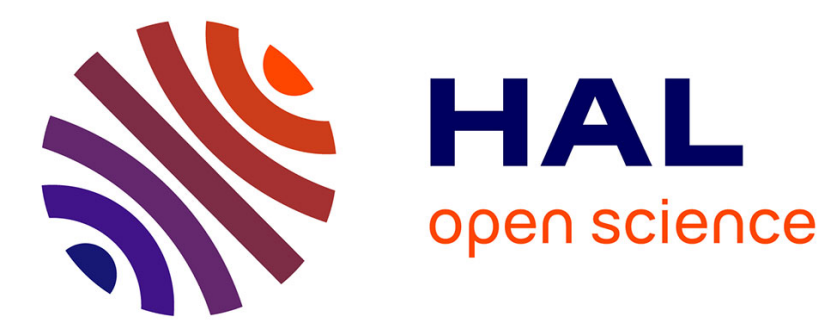

\title{
Addendum - Transport properties in a spin polarized gas, I and II
}

\author{
C. Lhuillier, F. Laloë
}

\section{To cite this version:}

C. Lhuillier, F. Laloë. Addendum - Transport properties in a spin polarized gas, I and II. Journal de Physique, 1982, 43 (5), pp.833-833. 10.1051/jphys:01982004305083300 . jpa-00209458

\section{HAL Id: jpa-00209458 https://hal.science/jpa-00209458}

Submitted on 1 Jan 1982

HAL is a multi-disciplinary open access archive for the deposit and dissemination of scientific research documents, whether they are published or not. The documents may come from teaching and research institutions in France or abroad, or from public or private research centers.
L'archive ouverte pluridisciplinaire HAL, est destinée au dépôt et à la diffusion de documents scientifiques de niveau recherche, publiés ou non, émanant des établissements d'enseignement et de recherche français ou étrangers, des laboratoires publics ou privés. 


\title{
Addendum
}

\author{
Transport properties in a spin polarized gas, I and II \\ C. Lhuillier and F. Laloë \\ (J. Physique 43 (1982) 197 and 225.)
}

Two references should be added to these articles. First, the theoretical discussion by E. P. Bashkin [1] of spin waves in a spin polarized gas. Second, the detailed calculation by A. E. Meyerovich [2] of the sound propagation and transport phenomena in a spin polarized ${ }^{3} \mathrm{He}-{ }^{4} \mathrm{He}$ liquid solution; in particular, this author discusses mode-couplings which are very similar to phenomena occurring in a spin polarized gas.

[1] Bashkin, E. P., Pis'ma Zh. Eksp. Teor. Fiz. 33 (1981) 11 ; J.E.T.P. Lett. 33 (1981) 8.

[2] Meyerovich, A. E., Sound and transport phenomena in spin-polarized ${ }^{3} \mathrm{He}-{ }^{4} \mathrm{He}$ solutions, to be published. 